African Crop Science Journal by African Crop Science Society is licensed under a Creative Commons Attribution 3.0 Uganda License. Based on a work at www.ajol.info/ and www.bioline.org.br/cs DOI: https://dx.doi.org/10.4314/acsj.v27i3.9

\title{
DIFFERENTIAL GRAIN YIELD PERFORMANCE OF SINGLE CROSS HYBRID MAIZE IN VARIED NITROGEN CONDITIONS
}

\author{
D.J. OGUNNIYAN ${ }^{1,3}$, D.K. OJO ${ }^{2}$, S.A. OLAKOJO ${ }^{1}$, S.A. MAKINDE ${ }^{3}$ and O.AOMIKUNLE ${ }^{3}$
}

${ }^{1}$ Institute of Agricultural Research and Training, Obafemi Awolowo University, Ibadan, Nigeria ${ }^{2}$ International Institute of Tropical Agriculture, Ibadan, Nigeria

${ }^{3}$ Department of Plant Breeding and Seed Technology, Federal University of Agriculture, Abeokuta, Nigeria

Corresponding author: dotunogunniyan@yahoo.com

(Received 24 March 2017; accepted 1 August 2019)

\begin{abstract}
Presence of genotypic differences in maize (Zea mays L.) grain yield in multi-environments would help plant breeders to make logical decisions in improvement programmes of the crop. Hence, the grain yield performance, heterosis and stability in hybrid maize in varied soil nitrogen $(\mathrm{N})$ conditions in Nigeria were assessed using multiple biometrical techniques. Grain yield performance, heterosis and stability of 150 single cross hybrid maize were assessed with checks in severe $\mathrm{N}$ stress, $\mathrm{N}$ stress and optimal conditions in a replicated trial laid out in $19 \times 8$ lattice design for 2 years. The grain yield was subjected to analysis of variance for each $\mathrm{N}$ condition and combined across years. Heterosis was estimated for the trait, additive mean effects and multiplicative interaction (AMMI); and genotype + genotype $\times$ environment (GGE) models were used to analyse the hybrids' yield stability. The AMMI captured $93.7 \%$; while GGE bi-plot accounted for $88.7 \%$ of total variation among the hybrids. Eight hybrids had high yields across the $\mathrm{N}$ conditions. Genotypes and environments affected heterosis for grain yield. Hybrids TZEI7×BD74-399, BD74-179×BD74-55 and BD74-175×BD74-147 were the most ideal genotypes for the $\mathrm{N}$ conditions; while severe $\mathrm{N}$ stress condition was ideal test environment. Hybrid BD74-170×BD74-31 adapted most to N stress; while TZEI1×BD74-399 adapted most to severe $\mathrm{N}$ stress and to optimal conditions. Based on yield, heterosis and stability, hybrids involving inbred line BD74-171 were recommended for N stress; while those with inbred lines TZEI1, TZEI4 BD74-170, BD74-128, BD74-179 and BD74-175 were adapted to N stress and optimal conditions.
\end{abstract}

Key Words: AMMI, GGE biplot, Zea mays

\section{RÉSUMÉ}

La présence de différences génotypiques dans le rendement en grains de maïs (Zea mays L.) dans plusieurs environnements aiderait les selectioneurs à prendre des décisions logiques dans les programmes d'amélioration de maïs. Par conséquent, les performances de rendement en grain, l'hétérosis et la stabilité d' hybride de maïs dans les diverses conditions d'azote $(\mathrm{N})$ du sol au Nigéria ont été 
évaluées à l'aide de multiples techniques biométriques. La performance de rendement en grain, l'hétérosis et la stabilité de 150 des hybrides de maïs simples croisés ont été évalués avec des contrôles du stress grave en $\mathrm{N}$, du stress en $\mathrm{N}$ et des conditions optimales dans le cadre d'un essai répété présenté sur un réseau $19 \times 8$ pendant 2 ans. Le rendement en grains a été soumis à une analyse de variance pour chaque condition d'azote et combiné sur plusieurs années. L'hétérosis a été estimée pour le trait, les effets moyens additifs et l'interaction multiplicative (MAIM); et des modèles génotype + génotype $\times$ environnement (GGE) ont été utilisés pour analyser la stabilité du rendement des hybrides. Le MAIM a capturé $93,7 \%$; alors que les bi-parcelles GGE ont représenté $88,7 \%$ de la variation totale parmi les hybrides. Huit hybrides ont eu des rendements élevés dans les conditions d'azote $(\mathrm{N})$ du sol. Les génotypes et les environnements ont affecté l'hétérosis pour le rendement en grain. Les hybrides TZEI7 × BD74-399, BD74-179 × BD74-55 et BD74-175 × BD74-147 étaient les génotypes les plus idéaux pour les conditions $\mathrm{N}$; tandis que la condition de stress $\mathrm{N}$ grave était l'environnement de test idéal. Les hybrides BD74-170 × BD74-31 étaient les mieux adaptés au stress N; TZEI1 × BD74-399 étaient plus adaptés à l' intense stress lié à l'azote et aux conditions optimales. En se basant sur le rendement, l'hétérosis et la stabilité, des hybrides impliquant la lignée consanguine BD74-171 ont été recommandés pour le stress sous N; tandis que ceux avec des lignées consanguines TZEI1, TZEI4 BD74-170, BD74128, BD74-179 et BD74-175 ont été adaptés au stress $\mathrm{N}$ et à des conditions optimales.

Mots Clés: MAIM, biplot GGE, Zea mays

\section{INTRODUCTION}

Maize (Zea mays L.) is an important cereal crop grown on at least 33 million hectares worldwide for food and feeds. It guarantees employment and income generation for families and businesses in the sub-Saharan Africa ((FAO, 2015). Though grain yield of the crop fluctuates between high and low due to the effects of climate and poor soil fertility, it is usually below expectation. Climates of the tropical Africa are characterised by high rainfall and solar radiation, thereby making the level of soil organic matter to be low and increasing nutrient leaching in the area. This has also resulted in poor soil fertility (Badu-Apraku $e t$ al., 2010; Ismaila et al., 2010). The main plant nutrient responsible for the poor soil fertility is nitrogen. Its availability in sufficient quantities in the growing period strongly influences productivity of the crop (Thomason et al., 2002). Consequently, fertiliser use as a strategy for replenishing soils with limiting nutrients becomes a critical component in improving the productivity of maize.

Maize performance varies within varieties across soil fertility and $\mathrm{N}$-use efficiency (Liang et al., 2005) due to variations that exist in gene expression of the crop for low $\mathrm{N}$ tolerance. Thus, newly developed hybrid maize needs to be tested in varied $\mathrm{N}$ conditions to ascertain their responses. Besides, yield is a complex quantitative trait, controlled by many genes, which are influenced by environments. Each gene has a small effect, which is significant in the total performance of the crop; thus the need for multi-environment trials (METs) to make accurate decisions. But selection of superior genotypes in METs usually results in $\mathrm{G} \times \mathrm{E}$ that complicates the interpretation of results obtained, and reduces efficiency in selecting the best genotypes. The interaction is the result of changes in genotype's performance across environments, due to differential responses of the genotypes to various abiotic and biotic factors (Kamdi, 2001; Aremu et al., 2007).

The $\mathrm{G} \times \mathrm{E}$ analysis is, therefore, required to provide unbiased estimates of yield and to determine yield stability across varied environmental variations. Several statistical techniques have been proposed to measure the stability of genotypes over environments in METs, but no single method can adequately 
explain cultivar performance across environments (Dehghani et al., 2006). The differences in genotype stability across environments had been assessed with AMMI model that scatters the genotypes according to their principal component values and GGE effects bi-plot by many authors (Gauch, 2006; Kaya et al., 2006; Yan and Tinker, 2006; Zerihun, 2011; Sibiya et al., 2013). The GGE bi-plot model displays, interprets and explores two important sources of variation, namely genotype main effect and $\mathrm{G} \times \mathrm{E}$ of MET data. The two models have been extensively used in trials to identify best genotype across environments and identify best genotypes for mega-environment (Yan and Tinker, 2006; Fan et al., 2007; Vita et al., 2010).

Heterosis is used to express the superiority of hybrids of maize over their parents. It has been used extensively in breeding maize for yield and other desirable traits plant breeders. High heterosis estimates have been observed for yield and other traits in crosses between maize genotypes (Venugopal et al., 2002; Amiruzzaman et al., 2010). Expression of heterosis for a trait is determined by the level of dominance controlling the traits (Falconer and Mackay, 1996) as cited by Mulualem and Abate (2016); hence grain yield in maize is expected to exhibit heterosis. The phenomenon also depends on the level of genetic divergence between parents. Therefore, expression of heterosis is expected to be higher in crosses between broad base germpasm of diverse origins. The extent to which each hybrid expresses heterosis may vary because of the wide variation in the performance of the parent lines used in this study. Therefore, this study employed multiple biometrical techniques to assess the grain yield performance, heterosis and stability in single cross hybrid maize in varied soil $\mathrm{N}$ conditions in Nigeria.

\section{MATERIALS AND METHODS}

Germplasm and experimental site. One hundred and fifty single cross maize hybrids were generated from 20 inbred lines, using North Carolina Design II mating design in 2013. The hybrids were evaluated in 2014 and 2015 to determine the variability in the grain yield of the hybrids in the varied soil $\mathrm{N}$ conditions. The trial was conducted in soil depleted of native $\mathrm{N}$ in Ibadan, Nigeria (3.56 E; $7.33^{\circ} \mathrm{N}$ and $168 \mathrm{~m}$ above sea level), before the trial commenced. Maize plants were planted in the experimental plot using high population density, without fertiliser application. The maize plants were uprooted shortly before flowering when the plants would have used up the native $\mathrm{N}$ in the soil. The soil was analysed for $\mathrm{N}$ and the process was repeated until the $\mathrm{N}$ had been depleted. Mean annual rainfall and temperature of the experimental site were $186.9 \mathrm{~mm}$ and $26.1{ }^{\circ} \mathrm{C}$, respectively.

Experimental layout and crop management. The experiment was laid out in $19 \times 8$ lattice design, with three replicates in the trial. Two check hybrids (TZEI7×TZEI4 and TZEI60×TZEI86) were evaluated along with the newly generated hybrids. Plots consisted of two rows of $5 \mathrm{~m}$ long and 0.75 $\mathrm{m}$ apart, where plants were spaced $0.5 \mathrm{~m}$ in a row. Three seeds were sown and later thinned at 2 WAP to two stands per hill, to attain a plant population of 53,333 plants hä.

There were three $\mathrm{N}$ concentrations in the soil: 0,30 and $90 \mathrm{~kg} \mathrm{~N}$ ha $^{-1}$ denoting severe $\mathrm{N}$ stress condition, $\mathrm{N}$ stress condition and optimal condition, respectively. Fertiliser was applied in the form of NPK 15:15:15 at $30 \mathrm{~kg}$ ha $^{-1}$ to each of $\mathrm{N}$ stress $\left(30 \mathrm{~kg} \mathrm{ha}^{-1}\right)$ and optimal $\left(90 \mathrm{~kg} \mathrm{ha}^{-1}\right)$ conditions plots at 4 WAP. Moreover, the plots with optimal $\mathrm{N}$ condition received additional $60 \mathrm{~kg} \mathrm{~N} \mathrm{ha}^{-1}$ in the form of urea to bring the total available $\mathrm{N}$ to $90 \mathrm{~kg}$ ha ${ }^{1}$ two weeks later. Urea was not applied to severe $\mathrm{N}$ stress plots, but all the plots received $60 \mathrm{~kg} \mathrm{Pha}^{-1}$ as SSP and $60 \mathrm{~kg} \mathrm{~K} \mathrm{ha}^{-1}$ as muriate of potash. The three $\mathrm{N}$-concentrations $\times$ two years represented six environments for the trial. Standard cultural practices were applied for field maintenance, harvesting and seed 
processing according to the recommendation of IAR\&T (2010).

Data collection and analysis. The ears of the plants were harvested when the bracts were dry. The grains were shelled and weighed, after which the moisture content was determined using a digital moisture tester. Grain yield adjusted to $15 \%$ moisture content was estimated as:

Grain yield $\left(\mathrm{kg} \mathrm{ha}^{-1}\right)=$

$\frac{\mathrm{GWT}(\mathrm{kg})}{7.5 \mathrm{~m}^{2}} \times \frac{(100-\mathrm{MC})}{(100-15)} \times 10,000 \mathrm{~m}^{2}$

Where:

GWT $=$ grain weight, $\mathrm{MC}=$ grain moisture content at harvest, storage moisture content $=15 \%$, plot area $=7.5 \mathrm{~m}^{2}$ and 1 ha $=10,000$ $\mathrm{m}^{2}$.

The grain yield data collected were subjected to analysis of variance using SAS (2009), separately and combined for each condition ( $\mathrm{N}$-concentration $\times 2$ years). Hybrids were considered fixed effects; while replicates and environments were considered as random effects. Best 19 and 10 poorest grain yielding hybrids were selected for further analysis. Mid-parent heterosis (MPH) and better-parent heterosis (BPH) for grain yield were calculated for the selected hybrids according to Comstock and Robinson (1952) as cited by (Tiwari et al., 2011) for each $\mathrm{N}$ condition as:

$$
\begin{aligned}
& \mathrm{MPH}=\frac{\mathrm{F}_{1}-\mathrm{MP}}{\mathrm{MP}} \times 100 \\
& \mathrm{BPH}=\frac{\mathrm{F}_{1}-\mathrm{BP}}{\mathrm{BP}} \times 100
\end{aligned}
$$

Where:

$\mathrm{F}_{1}$ was the grain yield of a hybrid, $\mathrm{MP}=\left(\mathrm{P}_{1}+\right.$ $\left.\mathrm{P}_{2}\right) / 2$ in which $\mathrm{P}_{1}$ and $\mathrm{P}_{2}$ were the yields of a given pair of inbred parents; and BP was the yield of the better parent.

Cluster analysis was performed on the heterosis estimates for grain yield of the selected hybrids, to distinguish them on their ability to express hybrid vigour using Paleontological Statistics software (PAST) ver. 2.03 (Hammer et al., 2001).

The AMMI models were also used to assess the grain yield of the selected hybrids across $\mathrm{N}$-environments, and investigate $\mathrm{G} \times \mathrm{E}$ effects. The GGE bi-plots were used on the yield means, adjusted for block effects according to Kang et al. (2006) to obtain information on the performance of the single cross hybrids and to provide information for identifying superior hybrids by assessing the $\mathrm{G}+\mathrm{G} \times \mathrm{E}$ and select stable hybrids. The GGE bi-plot was also used to identify high yielding and adapted hybrid maize and suitable test environment. Hybrids that had PC 1 score greater than 0 were identified as high yielding, and those that had PC 1 scores less than 0 were identified as low yielding. PC 1 scores greater than 0 detected the hybrids of interest (i.e. adaptable or high yielding), and PC 1 scores less than 0 discriminated the non-adaptable ones (Zerihun, 2011). The PC 2, which was related to genotypic stability or instability, divided the genotypes of interest based on their scores. Stability of the genotypes depends on their distance from the average environment abscissa (single head arrow). Hybrids closer to the abscissa are more stable than others.

\section{RESULTS}

Grain yield of the hybrid maize. There were significant differences in the grain yield of the 150 hybrid maize in $\mathrm{N}$ stress and optimal $\mathrm{N}$ conditions in the two years; while the trait significantly differed among the hybrids in severe $\mathrm{N}$ stress condition in 2015 and not severe N stress in 2014 (Table 1). Variation in performance of the 19 best and 10 poorest grain yielding hybrid maize with two checkhybrids across the six environments are also 
TABLE 1. Grain yield of best 19 and poorest 10 hybrid maize with two check hybrids evaluated in varied N conditions over 2014 and 2015 in Nigeria

\begin{tabular}{|c|c|c|c|c|c|c|c|c|}
\hline \multirow[t]{3}{*}{ Entry } & \multirow[t]{3}{*}{ Hybrid } & \multicolumn{2}{|c|}{ Severe N stress } & \multicolumn{2}{|c|}{$\mathrm{N}$ stress } & \multicolumn{2}{|c|}{ Optimal condition } & \multirow[t]{3}{*}{ Mean } \\
\hline & & 2014 & 2015 & 2014 & 2015 & 2014 & 2015 & \\
\hline & & \multicolumn{6}{|c|}{$------------\mathrm{kg} \mathrm{ha}^{1}---------$} & \\
\hline \multicolumn{9}{|c|}{ High grain yielding } \\
\hline 55 & TZEI1×BD74-399 & 1746.35 & 1277.07 & 5888.32 & 4297.19 & 8650.98 & 7345.26 & 4867.53 \\
\hline 129 & BD74-170×BD74-55 & 2016.17 & 2291.77 & 5248.03 & 4804.62 & 7110.05 & 7009.92 & 4746.76 \\
\hline 141 & BD74-175×BD74-152 & 1527.95 & 1923.41 & 5983.33 & 4418.70 & 7057.37 & 7270.11 & 4696.81 \\
\hline 128 & BD74-170×BD74-31 & 1096.65 & 1915.15 & 6613.39 & 5891.81 & 5186.29 & 5755.25 & 4409.76 \\
\hline 50 & BD74-128×TZEI188 & 1879.66 & 1862.06 & 4899.75 & 4168.12 & 6514.12 & 6996.05 & 4386.63 \\
\hline 140 & BD74-179×BD74-128 & 2061.11 & 1519.93 & 4824.46 & 4525.63 & 7391.58 & 5702.70 & 4337.57 \\
\hline 142 & BD74-175×BD74-147 & 1943.70 & 2100.32 & 4545.38 & 4699.16 & 6118.24 & 6565.03 & 4328.64 \\
\hline 60 & TZEI7×BD74-399 & 1024.84 & 1300.32 & 4740.88 & 5266.87 & 6417.65 & 6897.52 & 4274.68 \\
\hline 143 & BD74-175×BD74-31 & 1358.75 & 1804.12 & 4545.77 & 3827.25 & 6710.32 & 6757.80 & 4167.34 \\
\hline 147 & BD74-399×BD74-147 & 1297.45 & 1614.23 & 4130.08 & 4400.09 & 6866.60 & 6558.11 & 4144.43 \\
\hline 53 & TZEI1×BD74-179 & 1650.04 & 1427.24 & 5542.99 & 3756.52 & 7011.08 & 5439.41 & 4137.88 \\
\hline 139 & BD74-179×BD74-55 & 1053.90 & 1533.62 & 4165.51 & 4750.98 & 5719.83 & 7322.71 & 4091.09 \\
\hline 135 & BD74-171×BD74-128 & 1948.61 & 1693.21 & 4944.82 & 5005.28 & 5467.83 & 5474.85 & 4089.10 \\
\hline 57 & TZEI7×BD74-171 & 1933.98 & 1892.82 & 3908.77 & 3360.23 & 6080.03 & 7300.06 & 4079.32 \\
\hline 62 & TZEI22×BD74-171 & 1701.37 & 1287.26 & 4812.60 & 5307.79 & 5369.8 & 5534.30 & 4002.19 \\
\hline 130 & BD74-170×BD74-128 & 1569.73 & 1633.97 & 3993.13 & 4409.24 & 7143.71 & 5015.13 & 3960.82 \\
\hline 120 & BD74-175×TZEI106 & 1343.91 & 1695.69 & 6047.25 & 4765.78 & 4372.68 & 5497.30 & 3953.77 \\
\hline 4 & TZEI1×BD74-175 & 1461.89 & 1132.90 & 4350.86 & 3608.61 & 7073.25 & 5409.40 & 3839.49 \\
\hline 52 & TZEI1×BD74-171 & 1570.38 & 1284.42 & 3839.74 & 4207.31 & 4335.41 & 7643.32 & 3813.43 \\
\hline
\end{tabular}


TABLE 1. Contd.

\begin{tabular}{|c|c|c|c|c|c|c|c|c|}
\hline \multirow[t]{3}{*}{ Entry } & \multirow[t]{3}{*}{ Hybrid } & \multicolumn{2}{|c|}{ Severe N stress } & \multicolumn{2}{|c|}{$\mathrm{N}$ stress } & \multicolumn{2}{|c|}{ Optimal condition } & \multirow[t]{3}{*}{ Mean } \\
\hline & & 2014 & 2015 & 2014 & 2015 & 2014 & 2015 & \\
\hline & & \multicolumn{6}{|c|}{$------------\mathrm{kgha}^{-1}---------$} & \\
\hline \multicolumn{9}{|c|}{ Low grain yielding } \\
\hline 3 & TZEI1×TZEI4 & 899.55 & 957.63 & 2342.79 & 3498.79 & 2681.13 & 4651.35 & 2505.21 \\
\hline 39 & BD74-31×TZEI136 & 1417.18 & 699.87 & 3291.35 & 1844.14 & 3642.49 & 3327.31 & 2370.39 \\
\hline 69 & TZEI136×BD74-175 & 906.82 & 648.93 & 2850.11 & 2762.92 & 3045.82 & 3424.15 & 2273.13 \\
\hline 21 & TZEI188×TZEI2 & 522.31 & 519.35 & 1801.50 & 3408.30 & 3363.87 & 3981.55 & 2266.15 \\
\hline 38 & BD74-31×TZEI22 & 915.38 & 1142.02 & 2643.90 & 2925.68 & 2401.00 & 3494.03 & 2253.67 \\
\hline 75 & TZEI188×BD74-399 & 503.09 & 1570.77 & 1440.71 & 2890.43 & 3266.87 & 3491.29 & 2193.86 \\
\hline 90 & TZEI4×BD74-128 & 541.12 & 1091.62 & 1760.08 & 3179.59 & 2872.32 & 3392.67 & 2139.57 \\
\hline 10 & TZEI7×TZEI106 & 775.75 & 1290.21 & 1740.56 & 1348.51 & 3217.50 & 3869.44 & 2040.33 \\
\hline 59 & TZEI7×BD74-175 & 1153.10 & 1134.39 & 1755.82 & 2499.53 & 2118.90 & 2730.88 & 1898.77 \\
\hline 64 & TZEI22×BD74-175 & 393.83 & 830.69 & 1295.43 & 2551.91 & 1680.03 & 3321.57 & 1678.91 \\
\hline \multicolumn{9}{|c|}{ Checks } \\
\hline 151 & TZEI7×TZEI4 & 1999.46 & 2479.67 & 3934.12 & 3627.86 & 6007.96 & 6421.60 & 4078.45 \\
\hline 152 & TZEI60×TZEI86 & 2177.18 & 2420.19 & 4160.10 & 3941.04 & 6062.06 & 5914.00 & 4112.43 \\
\hline \multicolumn{9}{|c|}{ ANOVA } \\
\hline \multicolumn{2}{|c|}{ Grand mean } & 1404.52 & 1444.84 & 3650.98 & 3619.70 & 4705.24 & 5005.22 & \\
\hline \multirow{2}{*}{\multicolumn{2}{|c|}{$\begin{array}{l}\text { Genotype mean square } \\
\text { LSD }(0.05)\end{array}$}} & $417949.3^{\mathrm{ns}}$ & $400613.6^{* *}$ & $2629881.3^{* *}$ & $1617212.7^{* *}$ & $4655406.7^{* *}$ & $3146949.9^{* *}$ & \\
\hline & & 833.54 & 597.03 & 1016.7 & 622.66 & 1598.5 & 918.26 & \\
\hline
\end{tabular}

${ }^{\dagger}$ implies mean of the 150 single cross hybrids maize 
reported in Table 1. Fifteen of the 19 best hybrids had greater than $4000 \mathrm{~kg} \mathrm{ha}^{-1}$ grain yield across environments. Hybrids TZEI1×BD74-399 (55), BD74-170×BD74-31 (128), BD74-170×BD74-55 (129), BD74$175 \times$ BD74-152 (141) and BD74-175×BD74147 (142) had the highest grain yield across environments; while TZEI7×BD74-175 (59) and TZEI22×BD74-175 (64) produced the least grain yield across environments. Each of the hybrids produced grain yield greater than that of TZEI60×TZEI86 (better check hybrid).

Heterosis estimates. Variation in the heterosis was widest under severe $\mathrm{N}$ stress and $\mathrm{N}$ stress conditions compared to the optimal condition (Table 2). Estimates of both BPH and MPH were positive in the high grain yielding hybrids under the three $\mathrm{N}$ conditions. In the highest grain yielding hybrids under severe $\mathrm{N}$ stress, mean BPH was $55.93 \%$ and mean MPH was $68.3 \%$. Estimate of BPH was highest for hybrid BD74-175×BD74-147 (142) but MPH was highest for hybrid BD74-170×BD74-55 (129); while TZEI7×BD74-399 (60) had the least estimates for the two parameters. Only BD74128×TZEI188 (50) and BD74-175×BD74-147 (142) had heterosis greater than $100 \%$. Five of the 10 lowest yielding hybrids had negative $\mathrm{BPH}$ and MPH estimates; while the remaining had positive estimates. The low grain yielding hybrids had mean BPH and MPH estimates of 0.07 and $5.61 \%$, respectively; in the severe $\mathrm{N}$ stress condition. Hybrid TZEI1×TZEI4 (3) had least $\mathrm{BPH}$ and $\mathrm{MPH}$, whereas BD7431×TZEI22 (38) had the highest.

Hybrid TZEI22×BD74-171 (62) had the highest BPH and MPH estimates among the highest grain yielding hybrids in $\mathrm{N}$ stress. Hybrids expressed about $221 \%$ heterosis above their parents. But hybrid TZEI7×BD74-171 (57) had the least heterosis among the highest grain yielding hybrids. BPH and MPH estimates of the high yielding hybrids in $\mathrm{N}$ stress condition were 128.23 and $151.07 \%$, respectively. Only two hybrids, namely TZEI7×TZEI106 and TZEI7×BD74-175, out of the 10 lowest yielding hybrids had negative heterosis estimates. BPH and MPH for this set of hybrids were 25.08 and $33.77 \%$, respectively. Hybrid TZEI7×TZEI106 (10) and BD74-31×TZEI22 (38), respectively, had the least and highest heterosis estimates.

Only hybrid TZEI7×BD74-175 (59) had negative BPH estimate in optimal condition (Table 3); while the remaining hybrids (both highest and lowest grain yielding) had positive estimates. BPH estimate for highest grain yielding hybrids in optimal condition was 140.83\%; while MPH was $169.94 \%$. Hybrid BD74-175×BD74-152 (141) had the highest BPH (245.70\%) and MPH (268.88\%) among the highest yielding hybrids; while BD74$170 \times$ BD74-31 (128) had the least BPH (77.24\%) and MPH (134.57\%). BPH estimates for the lowest grain yield hybrids, in the optimal condition were 38.26 and $51.06 \%$ for $\mathrm{MPH}$. Hybrid TZEI7×BD74-175 (59) had the least BPH and MPH for the maize; while TZEI4×BD74-128 (90) and BD7431×TZEI136 (39), respectively had the highest BPH and MPH for the lowest yielding hybrids in optimal condition.

Based on the ability to express heterosis for grain yield, the selected hybrids were grouped into three (Fig. 1). All the poor grain yielding hybrids were grouped together; while the high yielding ones were grouped into two. Hybrids TZEI7×BD74-399 (60), BD74179×BD74-55 (139) and TZEI1×BD74-399 (55) were in cluster II; while hybrid BD74175×BD74-147 (142) and BD74-170×BD7431 (128) were in cluster I.

Grain yield stability. Significant variation due to genotypic effects existed for hybrid maize grain yield in the three $\mathrm{N}$ conditions across the two years; but the effect of year was significant only in optimal condition; while $\mathrm{G}$ $\times \mathrm{E}$ interaction had significant effects in $\mathrm{N}$ stress and optimal conditions (Table 3). Hybrids BD74-170×BD74-55 (129) and BD74175×BD74-147 (142) had the highest mean grain yield in severe $\mathrm{N}$ stress across the two years, with each of them having greater than $2000 \mathrm{~kg} \mathrm{ha}^{-1}$ (Table 3). 
TABLE 2. Heterosis estimates for grain yield of best 19 and poorest 10 white kernel hybrid maize evaluated in varied $\mathrm{N}$ conditions across 2014 and 2015 in Nigeria

\begin{tabular}{|c|c|c|c|c|c|c|c|}
\hline \multirow[t]{2}{*}{ Entry } & \multirow[t]{2}{*}{ Hybrid } & \multicolumn{2}{|c|}{ Severe N stress } & \multicolumn{2}{|c|}{$\mathrm{N}$ stress } & \multicolumn{2}{|c|}{ Optimal condition } \\
\hline & & BPH & MPH & $\mathrm{BPH}$ & MPH & BPH & MPH \\
\hline \multicolumn{8}{|c|}{ Highest grain yielding } \\
\hline 55 & TZEI1×BD74-399 & 27.80 & 40.89 & 128.96 & 128.97 & 155.98 & 177.83 \\
\hline 129 & BD74-170×BD74-55 & 84.95 & 119.38 & 104.40 & 121.79 & 128.48 & 146.44 \\
\hline 141 & BD74-175×BD74-152 & 88.29 & 90.51 & 186.04 & 242.93 & 245.70 & 268.88 \\
\hline 128 & BD74-170×BD74-31 & 10.77 & 37.67 & 152.44 & 226.70 & 77.24 & 134.57 \\
\hline 50 & BD74-128×TZEI188 & 102.81 & 109.70 & 124.76 & 136.60 & 144.02 & 203.88 \\
\hline 140 & BD74-179×BD74-128 & 78.14 & 88.43 & 151.02 & 164.97 & 146.81 & 199.46 \\
\hline 142 & BD74-175×BD74-147 & 107.68 & 111.37 & 141.00 & 146.08 & 137.96 & 170.67 \\
\hline 60 & TZEI7×BD74-399 & 0.62 & 8.65 & 114.56 & 115.93 & 152.98 & 156.63 \\
\hline 143 & BD74-175×BD74-31 & 63.44 & 78.48 & 128.94 & 162.66 & 233.30 & 272.76 \\
\hline 147 & BD74-399×BD74-147 & 61.24 & 63.89 & 91.30 & 108.02 & 154.03 & 157.60 \\
\hline 53 & TZEI1×BD74-179 & 42.76 & 54.06 & 109.46 & 142.45 & 93.27 & 111.19 \\
\hline 139 & BD74-179×BD74-55 & 50.27 & 58.52 & 123.34 & 149.90 & 148.02 & 153.22 \\
\hline 135 & BD74-171×BD74-128 & 87.62 & 108.70 & 180.26 & 205.05 & 123.76 & 159.96 \\
\hline 57 & TZEI7×BD74-171 & 76.03 & 76.30 & 60.41 & 89.81 & 163.92 & 176.16 \\
\hline 62 & TZEI22×BD74-171 & 31.00 & 50.82 & 221.00 & 221.36 & 137.04 & 153.65 \\
\hline 130 & BD74-170×BD74-128 & 35.69 & 61.32 & 71.42 & 96.79 & 103.46 & 165.77 \\
\hline 120 & BD74-175×TZEI106 & 51.30 & 61.33 & 181.98 & 190.68 & 108.35 & 124.07 \\
\hline 54 & TZEI1×BD74-175 & 24.85 & 37.47 & 81.67 & 101.36 & 117.19 & 162.10 \\
\hline \multirow[t]{2}{*}{52} & TZEI1×BD74-171 & 37.49 & 40.82 & 83.46 & 118.23 & 104.30 & 134.00 \\
\hline & Mean & 55.93 & 68.33 & 128.23 & 151.07 & 140.83 & 169.94 \\
\hline \multicolumn{8}{|c|}{ Lowest grain yielding } \\
\hline 3 & TZEI1×TZEI4 & -26.60 & -26.02 & 26.96 & 46.94 & 9.88 & 30.18 \\
\hline 39 & BD74-31×TZEI136 & 41.88 & 47.04 & 49.92 & 71.65 & 56.02 & 81.48 \\
\hline 69 & TZEI136×BD74-175 & -8.48 & 3.23 & 55.64 & 56.01 & 53.04 & 60.02 \\
\hline 21 & TZEI188×TZEI2 & -25.25 & -24.63 & 31.83 & 32.04 & 36.57 & 55.23 \\
\hline 38 & BD74-31×TZEI22 & 47.72 & 50.22 & 78.18 & 86.81 & 57.25 & 74.82 \\
\hline 75 & TZEI188×BD74-399 & 18.44 & 26.52 & -0.09 & 4.94 & 28.77 & 32.16 \\
\hline 90 & TZEI4×BD74-128 & -19.29 & -7.68 & 38.30 & 45.97 & 59.62 & 79.11 \\
\hline 10 & TZEI7×TZEI106 & -10.36 & -9.26 & -32.83 & -28.03 & 53.09 & 58.32 \\
\hline 59 & TZEI7×BD74-175 & 8.51 & 17.03 & -9.35 & -0.11 & -8.63 & 1.36 \\
\hline \multirow[t]{2}{*}{64} & TZEI22×BD74-175 & -25.89 & -20.32 & 12.27 & 21.44 & 36.97 & 37.90 \\
\hline & Mean & 0.07 & 5.61 & 25.08 & 33.77 & 38.26 & 51.06 \\
\hline
\end{tabular}

$\mathrm{BPH}$ and MPH indicate better parent heterosis and mid-parent heterosis, respectively 
TABLE 3. Grain yield of selected hybrid maize with two checks evaluated in varied $\mathrm{N}$ conditions combined over 2014 and 2015 in Nigeria

\begin{tabular}{|c|c|c|c|c|}
\hline \multirow[t]{2}{*}{ Entry } & \multirow[t]{2}{*}{ Hybrid } & \multicolumn{3}{|c|}{ Grain yield $\left(\mathrm{kg} \mathrm{ha}^{-1}\right)$} \\
\hline & & Severe N stress & $\mathrm{N}$ stress & Optimal condition \\
\hline 55 & TZEI1×BD74-399 & 1511.71 & 5092.76 & 7998.12 \\
\hline 129 & BD74-170×BD74-55 & 2153.97 & 5026.33 & 7059.99 \\
\hline 141 & BD74-175×BD74-152 & 1725.68 & 5201.02 & 7163.74 \\
\hline 128 & BD74-170×BD74-31 & 1505.9 & 6252.6 & 5470.77 \\
\hline 50 & BD74-128×TZEI188 & 1870.86 & 4533.94 & 6755.09 \\
\hline 140 & BD74-179×BD74-128 & 1790.52 & 4675.05 & 6547.14 \\
\hline 142 & BD74-175×BD74-147 & 2022.01 & 4622.27 & 6341.64 \\
\hline 60 & TZEI7×BD74-399 & 1162.58 & 5003.88 & 6657.59 \\
\hline 143 & BD74-175×BD74-31 & 1581.44 & 4186.51 & 6734.06 \\
\hline 147 & BD74-399×BD74-147 & 1455.84 & 4265.09 & 6712.36 \\
\hline 53 & TZEI1×BD74-179 & 1538.64 & 4649.76 & 6225.25 \\
\hline 139 & BD74-179×BD74-55 & 1293.76 & 4458.25 & 6521.27 \\
\hline 135 & BD74-171×BD74-128 & 1820.91 & 4975.05 & 5471.34 \\
\hline 57 & TZEI7×BD74-171 & 1913.4 & 3634.5 & 6690.05 \\
\hline 62 & TZEI22×BD74-171 & 1494.32 & 5060.2 & 5452.05 \\
\hline 130 & BD74-170×BD74-128 & 1601.85 & 4201.19 & 6079.42 \\
\hline 120 & BD74-175×TZEI106 & 1519.8 & 5406.52 & 4934.99 \\
\hline 54 & TZEI1×BD74-175 & 1297.4 & 3979.74 & 6241.33 \\
\hline 52 & TZEI1×BD74-171 & 1427.4 & 4023.53 & 5989.37 \\
\hline 3 & TZEI1×TZEI4 & 928.59 & 2920.79 & 3666.24 \\
\hline 39 & BD74-31×TZEI136 & 1058.53 & 2567.75 & 3484.9 \\
\hline 69 & TZEI136×BD74-175 & 777.88 & 2806.52 & 3234.99 \\
\hline 21 & TZEI188×TZEI2 & 520.83 & 2604.9 & 3672.71 \\
\hline 38 & BD74-31×TZEI22 & 1028.7 & 2784.79 & 2947.52 \\
\hline 75 & TZEI188×BD74-399 & 1036.93 & 2165.57 & 3379.08 \\
\hline 90 & TZEI4×BD74-128 & 816.37 & 2469.84 & 3132.5 \\
\hline 10 & TZEI7×TZEI106 & 1032.98 & 1544.54 & 3543.47 \\
\hline 59 & TZEI7×BD74-175 & 1143.75 & 2127.68 & 2424.89 \\
\hline 64 & TZEI22×BD74-175 & 612.26 & 1923.67 & 2500.8 \\
\hline$\varphi 151$ & TZEI7×TZEI4 & 2239.57 & 3780.99 & 6214.78 \\
\hline$\varphi 152$ & TZEI60×TZEI86 & 2298.69 & 4050.57 & 5988.03 \\
\hline \multicolumn{2}{|c|}{ Grand mean } & 1424.68 & 3844.23 & 4855.23 \\
\hline \multicolumn{2}{|c|}{ Genotype mean square } & $461870.05^{* * *}$ & $2824967.00^{* * *}$ & $4991746.60^{* * * *}$ \\
\hline \multicolumn{2}{|c|}{ Year mean square } & $383710.99^{\mathrm{ns}}$ & $223057.00^{\mathrm{ns}}$ & $20518337.00^{* * * *}$ \\
\hline \multicolumn{2}{|c|}{ Genotype $\times$ year mean square } & $267316.07^{\mathrm{ns}}$ & $1063090.60^{* * *}$ & $2045634.10^{* * * *}$ \\
\hline \multicolumn{2}{|l|}{ LSD } & 531.02 & 604.55 & 913.16 \\
\hline
\end{tabular}

$\dagger=$ implied mean of the 150 single cross hybrids maize, $\varphi=$ check hybrid, ${ }^{\text {ns }}=$ non-significant and ${ }^{* * *}=$ significant $(\mathrm{P}<0.001)$ 


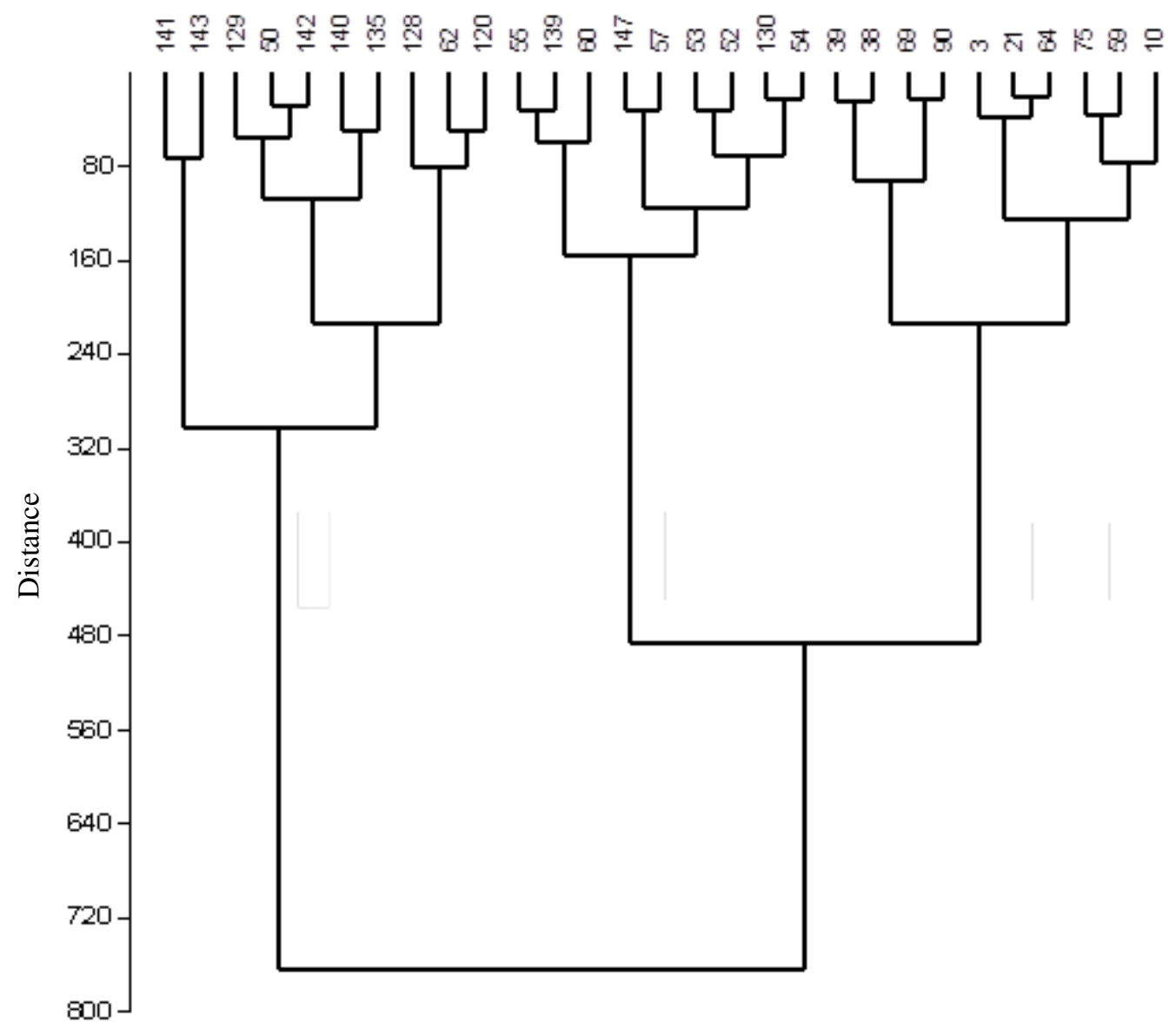

Figure 1. Relationship among heterosis for grain yield of best 19 and poorest 10 hybrid maize evaluated in varied $\mathrm{N}$ conditions in 2014 and 2015 in Nigeria.

Hybrids TZEI7×TZEI4 (21) and TZEI22x BD74-175 (64) were among those with the least mean grain yield across the two years. None of the hybrids had grain yield greater than the check hybrids.

In $\mathrm{N}$ stress and optimal conditions across years, however, hybrids TZEI1×BD74-399 (55), BD74-170×BD74-55 (129), BD74175×BD74-152 (141), BD74-170×BD74-31 (128) and TZEI7×BD74-399 (60) were among the hybrids that had the highest grain yields. Hybrids TZEI1×BD74-399 (55), BD74170×BD74-55 (129) and BD74-175×BD74152 (141) had greater than $5000 \mathrm{~kg} \mathrm{ha}^{-1}$ in $\mathrm{N}$ stress condition; while the three hybrids had greater than $7000 \mathrm{~kg} \mathrm{ha}^{-1}$ in optimal condition.
Grain yields of BD74-170×BD74-55 (129) and BD74-175×BD74-152 (141) across the two years were greater than $7000 \mathrm{~kg} \mathrm{ha}^{-1}$. Hybrids BD74-170×BD74-31 (128) and BD74$175 \times$ TZEI106 (120) had higher grain yield in $\mathrm{N}$ stress than in the optimal condition. BD74$170 \times$ BD74-31 (128) yielded $6252.6 \mathrm{~kg} \mathrm{ha}^{-1}$ and $5470.77 \mathrm{~kg} \mathrm{ha}^{-1}$ in $\mathrm{N}$ stress and optimal condition, respectively; while BD74-175x TZEI106 (120) produced $5406.52 \mathrm{~kg} \mathrm{ha}^{-1}$ grain in $\mathrm{N}$ stress and $4934.99 \mathrm{~kg} \mathrm{ha}^{-1}$ in optimal condition. Eight hybrids had significantly higher grain yield than TZEI60×TZEI86 (better check) in N stress, but only TZEI1×BD74399 (55) was significantly different from 
TZEI7×TZEI4 (better check) in optimal condition.

AMMI analysis for grain yield. The AMMI bi-plot (PC 1 vs. means) analysis for grain yield of the hybrids in the six different $\mathrm{N}$ conditions is presented in Figure 2. The X-coordinate indicates the main effects (mean grain yield) and the Y-coordinate indicates the effects of the interaction (PC 1). Values closer to the origin of the axis (PC 1) provide a smaller contribution to the interaction than those that are further away. About $86 \%$ of the variation in the grain yield was due to genotype $\times$ environment $(\mathrm{G} \times \mathrm{E})$ total sum of squares, leaving the rest $(13.8 \%)$ as residual. Both environments and hybrids were clustered into three out of the four segments of the plot. Hybrids TZEI1×BD74-171 (52), TZEI22 $\times$ BD74-171 (62), BD74-171× BD74-147 (132), BD74-171×BD74-128 (135), TZEI7×TZEI4 (151), BD74-170×BD74-31 (128) and BD74-175×BD74-147 (142) had very small absolute PC 1 scores; while TZEI1×BD74-399 (55), BD74-175×BD74-152 (141) and BD74-170×BD74-55 (129) had highest yield and interaction with environments.

The $\mathrm{G} \times \mathrm{E}$ interaction was the least in 30N_14, 30N_15 and 90N_15, but higher in 0N_14, 0N_15 and 90N_14. Environment $30 \mathrm{~N} \_15$ was slightly positively related to the $\mathrm{G} \times \mathrm{E}$, whereas $0 \mathrm{~N} \_14$ and $0 \mathrm{~N} \_15$ were highly positively related with the interaction.

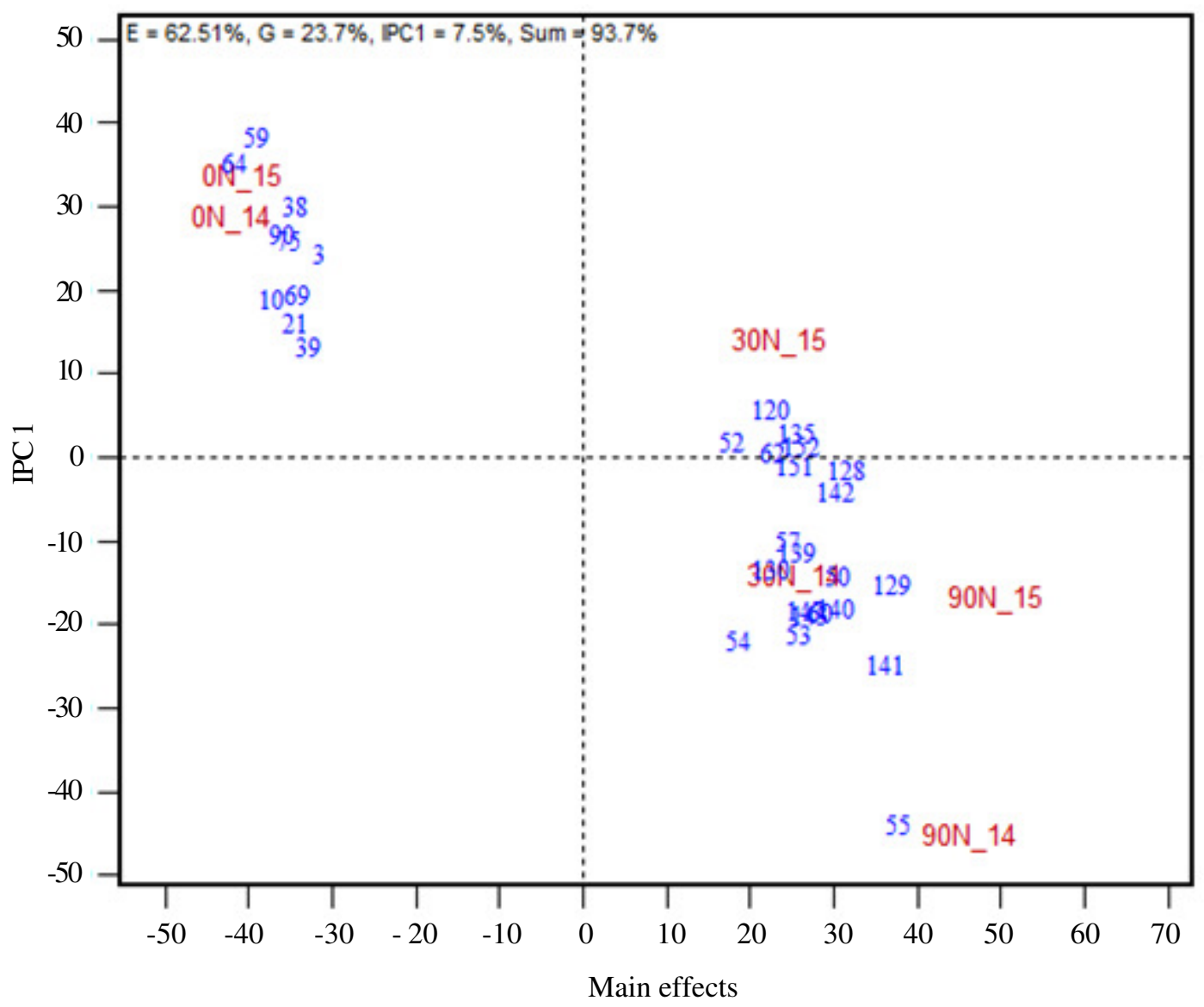

Figure 2. AMMI bi-plot of the mean grain yield of best 19 and poorest 10 the hybrid maize with two check-hybrids evaluated in varied N conditions in 2014 and 2015 in Nigeria. 
Furthermore, 30N_14 and 90N_15 had lower negative interactions than 90N_14. Figure 2 shows that no genotype had low interaction relationships with the poorest environment.

GGE analysis for grain yield. Figure 3 presents grain yield versus stability view of the best 19 and 10 poorest with two checkhybrids of the maize as measured by principal components in varied $\mathrm{N}$ conditions. Partitioning GGE through biplot analysis, shows that PC 1 and PC 2, respectively, accounted for 80.7 and $8.0 \%$ of variation, totalling of $88.7 \%$ for grain yield of the maize. Grain yield increased in the direction of double head arrow that project the hybrids on average environment axis (AEA). Hybrids TZEI1×BD74-399 (55), BD74-175×BD74-152 (141), BD74-170×BD74-55 (129), TZEI7×BD74-399 (60) and BD74-170×BD74-
31 (128) were among the highest yielders; whereas those with least yields were TZEI7×BD74-175 (59) and TZEI22×BD74175 (64) and TZEI7×TZEI106 (10). Based on this, the high yielding hybrids were in the order of stability as TZEI7×BD74-399 (60) Ã BD74175×BD74-152 (141) ̃̃ BD74-170×BD74-55 (129) Ã TZEI1×BD74-399 (55) Ã BD74170 $\times$ BD74-31 (128); whereas only hybrids BD74-31×TZEI136 (39) and TZEI188×BD74399 (75) were among the least yielders that were stable. Hybrids TZEI7×BD74-399 (60), BD74-179 $\times$ BD74-55 (139) and BD74$175 \times$ BD74-147 (142) were closer to the ideal genotype small circle on the average environment axis. In this study, 0N_14 and 0N_15 fell within the centre of concentric circles, that is the innermost circle.

The which-won-where biplot (Fig. 4), shows that lines to the sides of the polygon

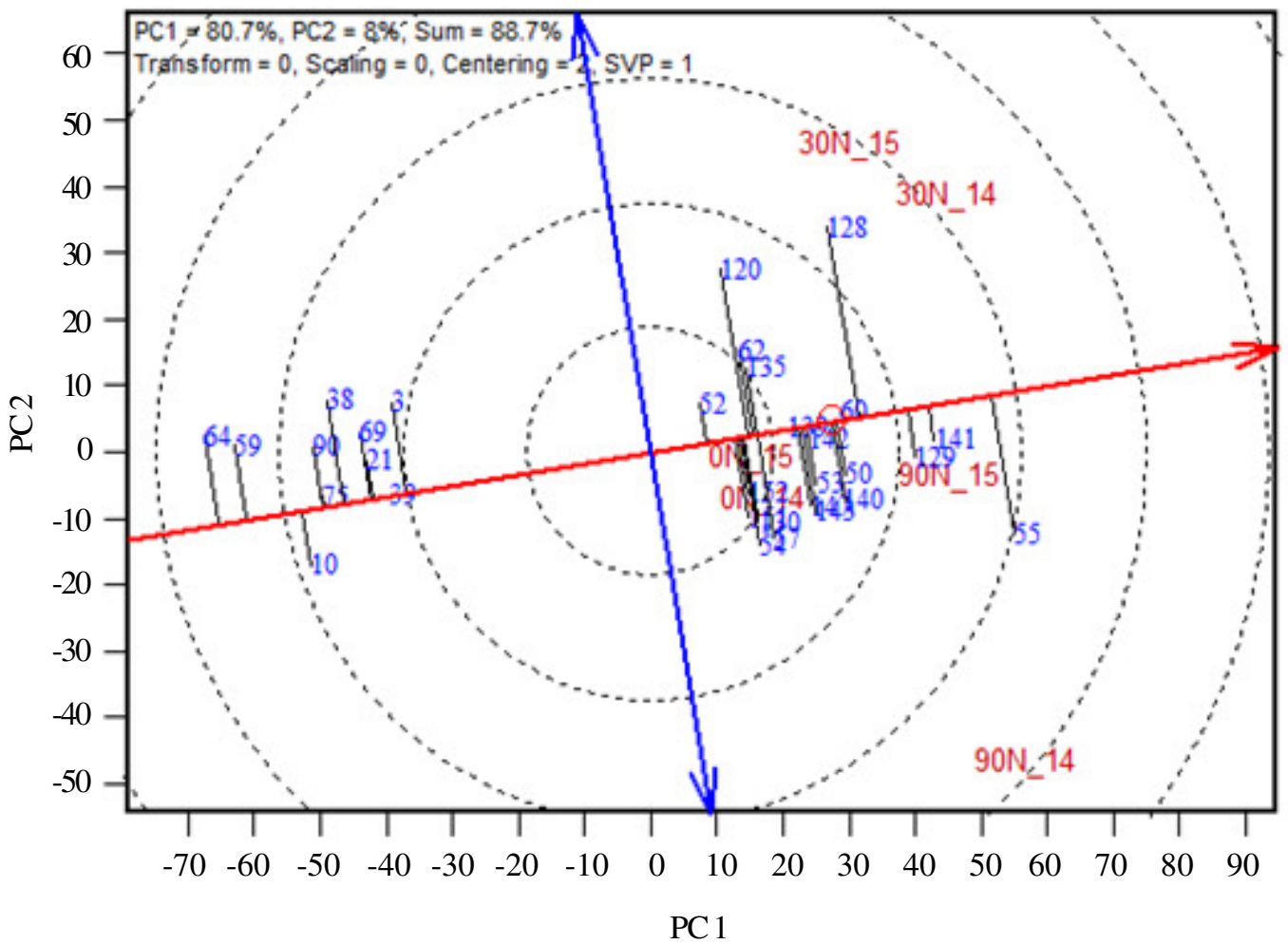

Figure 3. Mean vs stability view of the mean grain yield of best 19 and poorest 10 the hybrid maize with two check-hybrids as measured by principal com-ponents in varied $\mathrm{N}$ conditions in 2014 and 2015 in Nigeria. 


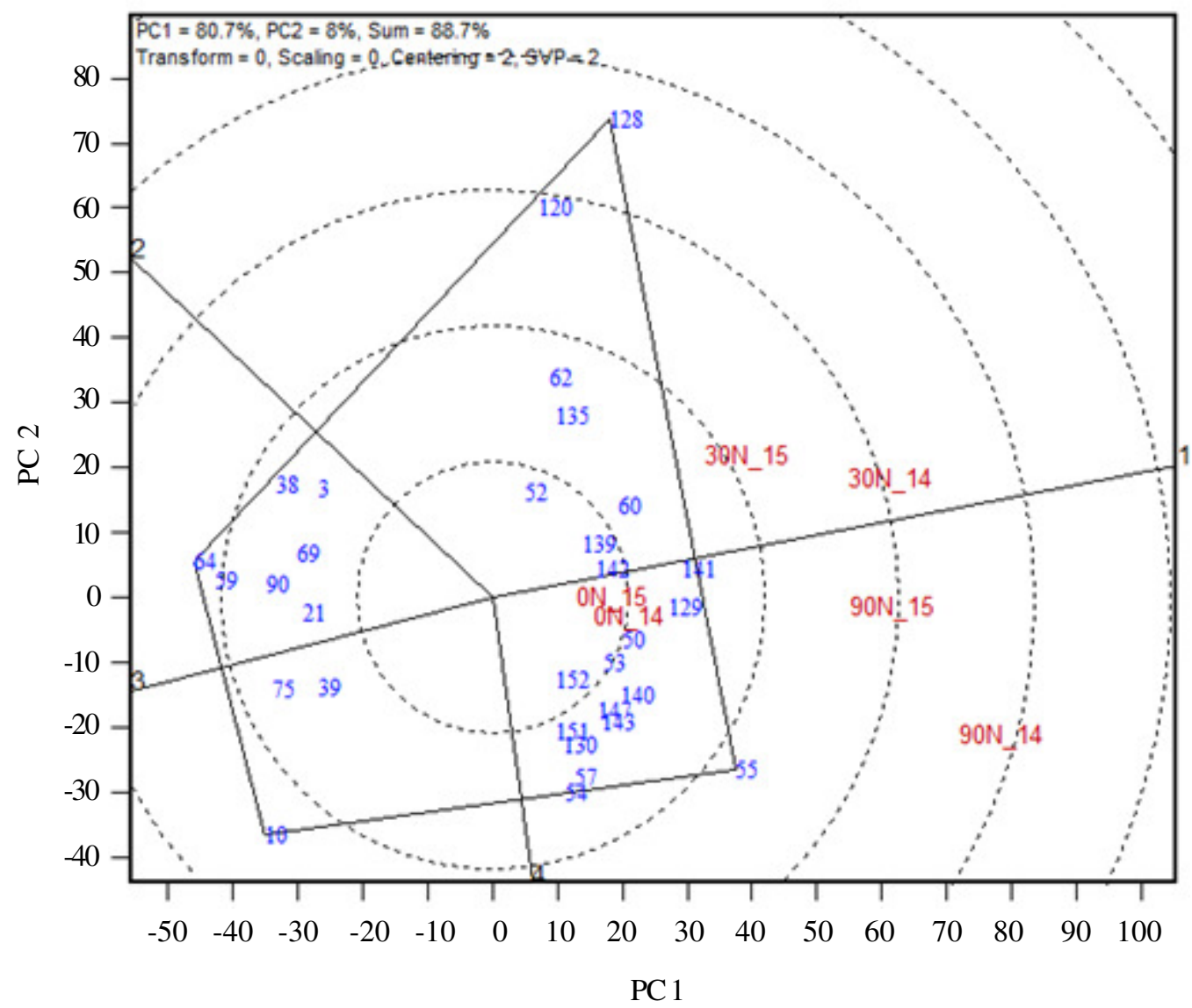

Figure 4. The "which-won-where" view of the GGE bi-plot based on the G×E data of the mean grain yield of best 19 and poorest 10 hybrid maize with two check-hybrids evaluated in varied $\mathrm{N}$ conditions in 2014 and 2015 in Nigeria.

drawn from the origin, divided the six conditions into four sectors. Environments 30N_14 and 30N_15 clustered into one; while N_14, 0N_15, 90N_14 and 90N_15 into another. Hybrids BD74-170×BD74-31 (128), TZEI1×BD74-399 (55), TZEI7×TZEI106 (10) and TZEI22 $\times$ BD74-175 (64) formed the vertices of the polygon. The bi-plot revealed best hybrids in different environments and accurately identified the best hybrid with respect to each mega-environment. Hybrid BD74-170×BD74-31 (128) was the best for mega-environment 30N_14 and 30N_15; while hybrid TZEI1 $\times$ BD74-399 (55) was the best for $0 \mathrm{~N} \_14,0 \mathrm{~N} \_15,90 \mathrm{~N} \_14$ and 90N_15 mega-environment. Hybrids TZEI22×BD74-
175 (64) and TZEI7×TZEI106 (10) were the best in environments not considered in this trial based on their locations on the biplots. Hybrid TZEI1×BD74-399 (55) had the highest PC 1 score and relatively small PC 2 (about -25 ). In contrast, hybrid TZEI7×TZEI106 (10) had small PC 1 score ( $\tilde{A}-30)$ and relatively high PC 2 score $(\tilde{A}-30)$. The best 19 and two check-hybrids had PC 1 greater than 0 but the 10 poorest had PC 1 less than 0.

\section{DISCUSSION}

The hybrid maize, especially highest yielding ones, responded positively to increase in $\mathrm{N}$ concentrations (Table 1). However, hybrids 
BD74-170×BD74-31 (128) and BD74$175 \times$ TZEI106 (120) had higher grain yield in $\mathrm{N}$ stress, suggesting the hybrids are $\mathrm{N}$ stress tolerant. The positive and negative heterosis estimates for the grain yield indicate that some of the parents had favourable contribution; while the remaining contributed adversely to expression of the trait. Thus, crosses between high and low combiners are possible. This finding is in agreement with the report that interaction can exist between dominant alleles from good general combiner and recessive allele from poor combiner (Senthil and Bharathi, 2009). The adverse effects were more prominent under severe $\mathrm{N}$ stress, showing interactive effects of the genotype and environment. This may be responsible for the higher number of low grain yielding hybrids exhibiting negative heterosis. Most of the hybrids exhibited high positive heterosis for grain yield, in the six $\mathrm{N}$ conditions, confirming positive response of the hybrids to increased N. Only two hybrids, namely BD74128×TZEI188 (50) and BD74-175×BD74-147 (142), had heterosis greater than $100 \%$ in severe $\mathrm{N}$, and the hybrids were among those that exhibited highest heterosis in $\mathrm{N}$ stress and optimal conditions. Hence, they are adjudged promising, which may be further studied for possible release for farmers' use.

It is noteworthy that almost $50 \%$ of the hybrid maize showed heterosis greater than mean estimates for the grain yield in all the $\mathrm{N}$ conditions, confirming the observation that heterosis can be used for maize improvement (Amiruzzaman et al., 2010). Out of the 19 high yielding hybrids that had high heterosis advantage over their parents, 8 (42\%) were between inbred lines of different institutions (IITA and CIMMYT). This confirms a large variability among the inbred lines from different origins. The low grain yield yielding hybrids clustered together, despite that they were adapted to different environments. This shows the degrees in ability of the hybrids to express vigour advantage over their parents in specific environments. This proves that heterosis pivots on genetic ability of the crop. Though the high yielding hybrids clustered into two, the clusters did not represent adapted environments. This suggests that environments are equally important in heterosis expression.

The results that AMMI biplot explained 93.7\%; while the GGE biplot accounted for $88.7 \%$ of the variation among the hybrid maize, shows a slight difference in the variation captured by the two models. It reveals that AMMI is more efficient in accounting for variation more than the GGE model. This result contrasted with the observations of Mitrovic et al. (2012) that estimation of the performance of maize genotypes with AMMI and GGE biplot models was similar, but agreed with reports of Yan et al. (2007) that the GGE is preferred to AMMI graph in mega-environment analysis and genotype evaluation. However, the two biplots adequately captured variation due to the $\mathrm{G} \times \mathrm{E}$ in this study. According to Ebdon and Gauch (2002), hybrids TZEI1×BD74-171 (52), TZEI22×BD74-171 (62), BD74-171× BD74-147 (132), BD74-171×BD74-128 (135), TZEI7×TZEI4 (151), BD74-170×BD74-31 (128), BD74-399 $\times$ BD74-31 (148) and BD74175×TZEI106 (120), which appeared closer to the origin of the plot were the best hybrids as their high yields were consistent in the six environments. The hybrids can, therefore, be recommended for use in any of the environments.

High yielding TZEI7×BD74-175 (59), TZEI22×BD74-175 (64), BD74-175×BD74152 (141) and TZEI1×BD74-399 (55) were among the hybrids that were farther away from the origin (Fig. 2), indicating that they interacted highly with the environments. Therefore, they were largely unstable and their performance cannot be reliably predicted. However, the BD74-175×BD74-152 (141), TZEI1×BD74-399 (55) and BD74-170×BD7455 (129) were the best in 30N_14, 90N_14 and 90N_15; but TZEI1 $\times$ TZEI4 (3) and BD74$31 \times$ TZEI136 (39) were the best in 0N_14 and $0 \mathrm{~N} \_15$ for their relatively high main effect on 
the plot. The hybrids can be selected for these respective $\mathrm{N}$ conditions.

Relative magnitude and direction of genotypes along the abscissa and ordinate axes in a biplot is important to understand the response pattern of genotypes across environments (Yan and Kang, 2003). Best genotype should combine high yield and stable performance across environments. An ideal genotype is the highest yielding across test environments, and it is absolutely stable in performance (Yan and Kang, 2003). An ideal genotype which is usually used as reference for evaluating others may not exist in nature, but a genotype is more desirable if it is located closer such genotype (Mitrovic et al., 2012). In the present study, hybrids TZEI7 $\times$ BD74399 (60), BD74-179×BD74-55 (139) and BD74-175×BD74-147 (142) were most desirable because they were closest to the ideal genotype. Similarly, an environment is more desirable if it is located closer to the ideal environment which may not be easily identified (Yan and Kang, 2003). An ideal environment can be used for genotype selection in the METs.

Using the ideal environment as the centre, concentric circles are drawn to help visualise the distance between each environment and the ideal environment. The centre of concentric circles is an ideal test environment for being the most representative of the overall environments and the most powerful to discriminate genotypes (Yan and Rajcan, 2002). Based on this, severe $\mathrm{N}$ stress (0N_14 and 0N_15) were the ideal test environments out of the six environments for the maize.

Hybrids TZEI22×BD74-175 (64) and TZEI7×TZEI106 (10) formed two vertices of the polygon formed by the GGE biplot, but they cannot be recommended for any of the $\mathrm{N}$ conditions because they did not fall within any of the sectors representing the environments. Hybrid BD74-170×BD74-31 (128) is most adapted to N stress (30N_14 and 30N_15), which formed a megaenvironment. However, hybrid TZEI1×BD74-
399 (55) adapted most to mega-environment $\left(0 \mathrm{~N} \_14,0 \mathrm{~N} \_15,90 \mathrm{~N} \_14\right.$ and $90 \mathrm{~N} \_15$ representing $\mathrm{N}$ stress and optimal conditions) because they formed vertices in the sectors which the environments were located. Other hybrids that were adapted to $\mathrm{N}$ stress megaenvironment were BD74-170×BD74-31 (128), BD74-175×TZEI106 (120), TZEI22×BD74171 (62), BD74-171×BD74-128 (135), TZEI1×BD74-171 (52), TZEI7×BD74-399 (60) and BD74-179 $\times$ BD74-55 (139). Hybrids BD74-170×BD74-55 (129), BD74-128 $\times$ TZEI188 (50), TZEI1×BD74-179 (53), BD74-179 ×BD74-12 (140), BD74175×BD74-147 (142), BD74-175×BD74-31 (143), BD74-170×BD74-128 (130), TZEI7×BD74-171 (57) and TZEI1 $\times$ BD74-175 (54) were also adapted to the $\mathrm{N}$ stress and optimal conditions.

Two hybrids, namely BD74-128×TZEI188 (50) and BD74-175×BD74-147 (142), which were high yielding, had high heterosis estimates and were relatively stable across locations (Fig. 3). In fact, hybrid BD74-175×BD74-147 (142) was closest to the ideal genotype. A direct relationship is suspected between heterosis and grain yield, but not heterosis and adaptability of the maize because hybrids such as TZEI1×BD74-399 (55), BD74-170×BD7431(128) and BD74-175×TZEI106 (120) had high yield and high heterosis, but they are largely environment specific. The yields of the hybrids were not stable across $\mathrm{N}$ conditions. Hybrids TZEI7×BD74-399 (60) and BD74$179 \times$ BD74-55 (139), which were closer to ideal genotype were related to hybrid TZEI1×BD74-399 (55), which was best in severe $\mathrm{N}$ stress and optimal conditions. This is expected since any hybrid close to the ideal genotype is adapted to all the environments. This result was also confirmed by the relatedness of hybrid BD74-175×BD74-147 (142) and BD74-170×BD74-31 (128) in this study (Fig. 4). The two hybrids had high grain yield and high heterosis, but yield of BD74175×BD74-147 (142) was stable; while high 
yield of BD74-170×BD74-31 (128) was only specific.

Although, the GGE biplot analysis interpreted $\mathrm{G} \times \mathrm{E}$ interactions more than AMMI, both methods displayed their importance and innovativeness in analysing and interpreting the interactions. This will enable maize breeders to make more accurate decisions in their maize improvement programmes. With respect to grain yield, superior hybrids of inbred line BD74-171 are recommended for $\mathrm{N}$ stress condition; whereas those with inbred lines TZEI1, TZEI4 BD74170, BD74-128, BD74-179 and BD74-175 were adapted to severe $\mathrm{N}$ stress and optimal mega-environments. The stable hybrids are recommended for both $\mathrm{N}$ stress and optimum $\mathrm{N}$ conditions. Both genotypes and environment are important for heterosis for grain yield in maize. Inter-institutional parent lines complement one another in maize improvement and exchange of germplasm should be encouraged in maize breeding.

\section{REFERENCES}

Amiruzzaman, M., Islam, M.A., Hassan, L. and Rohman, M.M. 2010. Combining ability and heterosis for yield and component characters in maize. Academic Journal of Plant Science 3(2):79-84.

Aremu, C.O., Ariyo, O.J. and Adewale, B.D. 2007. Assessment of selection techniques in genotype $x$ environment interaction in cowpea Vigna unguiculata (L.) walp. African Journal of Agricultural Research 2(8):352-355.

Badu-Apraku, B., Menkir, A., Ajala, S., Akinwale, R., Oyekunle, M. and ObengAntwi, K. 2010. Performance of tropical early-maturing maize cultivars in multiple stress environments. Canadian Journal of Plant Science 90:831-852.

Dehghani, H., Ebadi, A. and Yousefi, A. 2006. Bi-plot analysis of genotype by environment interaction for barley yield in Iran. Agronomy Journal 98: 388-393.
Ebdon, J.S. and Gauch, H.G. 2002. Additive main effect and multiplicative interaction analysis of national turfgrass performance trials: I. Interpretation of genotype $x$ environment interaction. Crop Science 42: 489-496.

Fan, X.M., Kang, M.S., Chen, H., Zhang, Y.T. and $\mathrm{Xu}$, J.C. 2007. Yield stability of maize hybrids evaluated in multi-environment trials in Yunnan, China. Agronomy Journal 99:220-228.

FAO. 2015. FAOSTAT. Food and Agriculture Organization of the United Nations, Rome, Italy. http://Faostat.fao.org.

Gauch, H.G. 2006. Statistical analysis of yield trials by AMMI and GGE. Crop Science 46:1488-1500.

Hammer, O., Harper, D.A.T. and Ryan, P.D. 2001. PAST: Palaeontological Statistics Software Package for Education and Data Analysis. Palaeontologia Electronica 4: 9.

IAR\&T. 2010. Institute of Agricultural Research \& Training. Farmers' Guide Series 1. No. 4: Guide on maize production. Obafemi Awolowo University, Ibadan. 7p.

Ismaila, U., Gana, A.S., Tswanya, N.M. and Dogara, D. 2010. Cereals production in Nigeria: Problems, constraints and opportunities for betterment. African Journal of Agricultural Research 5(12):1341-1350.

Kamdi, R.E. 2001. Relative stability, performance and superiority of crop genotypes across environments. Journal of Agricultural Biology, Environment and Statistics 6:449-460.

Kang, M.S., Aggarwal, V.D. and Chirwa, R.M. 2006. Adaptability and stability of bean cultivars as determined via yield-stability statistics and GGE bi-plot analysis. Journal of crop Improvement 15:97-120.

Kaya, Y., Akcura, M. and Taner, S. 2006. GGE bi-plot analysis of multi-environment yield trials in bread wheat. Turkish Journal of Agriculture and Forestry 30:325-337.

Liang, C., Guohua, M.I., Jiansheng, L.I., Fanjun, C. and Fusuo, Z. 2005. Genetic 
analysis of maize root characteristics in response to low nitrogen stress. Plant and Soil 276 (1-2):369-382.

Mitrovic, B., Stanisavljevi, D., Treski, S., Stojakovic, M., Ivanovic, M., Bekavac, G. and Rajkovic, M. 2012. Evaluation of experimental maize hybrids tested in multilocation trials using AMMI and GGE biplot analyses. Turkish Journal of Field Crops 17:35-40.

Mulualem, T. and Abate, M. 2016. Heterotic Response in Major Cereals and Vegetable Crops. International Journal of Plant Breeding and Genetics 10:69-78.

SAS. 2009. SAS Institute user's guide: Statistics, version 9.0. SAS Institute Incorporated, Cary, North Carolina, USA. $1028 \mathrm{pp}$.

Senthil, K.P. and Bharthi, P. 2009. Studies on relationship between GCA and SCA effects in maize (Z. mays L.). Electronic Journal of Plant Breeding 1:24-27.

Sibiya, J., Tongoona, P. and Derera, J. 2013. Combining ability and GGE bi-plot analyses for resistance to northern leaf blight in tropical and subtropical elite maize inbred lines. Euphytica 91(2): 245-257.

Thomason, W.E., Raun, W.R., Johnson, G.V., Freeman, K.W., Wynn, K.J. and Mullen, R.W. 2002. Production system techniques to increase nitrogen use efficiency in winter wheat. Journal of Plant Nutrition 25:22612283.

Tiwari, D.K., Pandey, P., Giri, S.P. and Dwivedi, J.L. 2011. Prediction of gene action, heterosis and combining ability to identify superior rice hybrids. International Journal of Botany 7:126-144.

Venugopal, M., Ansani, N.A. and Murthy, G.K. 2002. Heterosis and its component characters in maize (Zea mays L.). Crop Research 3:72-74.

Vita, P., Mastrangeloa, A., Matteua, L., Mazzucotellib, E., Virzi, N., Palumboc, M., Stortod, M., Rizzab, F. and Cattivelli, L. 2010. Genetic improvement effects on yield stability in durum wheat genotypes grown in Italy. Field Crop Reserach 119:68-77.

Yan, W. and Kang, M.S. 2003. GGE bi-plot analysis: A graphical tool for breeders, geneticists and agronomists. CRC Press, Boca Raton, FL.

Yan, W. and Rajcan, I. 2002. Bi-plot evaluation of test sites and trait relations of soybean in Ontario. Crop Science 42:11-20.

Yan, W. and Tinker, N.A. 2006. Bi-plot analysis of multi-environment trial data: Principles and applications. Canadian Journal of Plant Science 86:623-645.

Yan, W., Kang, M.S., Ma, B., Woods, S. and Cornelius, P.L. 2007. GGE bi-plot vs. AMMI analysis of genotype-byenvironment data. Crop Science 47:643655.

Zerihun, J. 2011. GGE-bi-plot analysis of multienvironment yield trials of barley (Hordeium vulgare L.) genotypes in Southeastern Ethiopia highlands. International Journal of Plant Breeding and Genetics 5: 59-75. 